\title{
Cardiovascular and metabolic influences of fetal smoke exposure
}

\author{
Hanneke Bakker $\cdot$ Vincent W. V. Jaddoe
}

Received: 12 August 2011/ Accepted: 30 September 2011/Published online: 13 October 2011

(C) The Author(s) 2011. This article is published with open access at Springerlink.com

\begin{abstract}
Many epidemiological studies showed associations of low birth weight with cardiovascular disease, type 2 diabetes and obesity. The associations seem to be consistent and stronger among subjects with a postnatal catch up growth. It has been suggested that developmental changes in response to adverse fetal exposures might lead to changes in the fetal anatomy and physiology. These adaptations may be beneficial for short term, but may lead to common diseases in adulthood. Maternal smoking during pregnancy is one of the most important adverse fetal exposures in Western countries, and is known to be associated with a $150-200 \mathrm{~g}$ lower birth weight. An accumulating body of evidence suggests that maternal smoking during pregnancy might be involved in pathways leading to both low birth weight and common diseases, including cardiovascular disease, type 2 diabetes and obesity, in adulthood. In this review, we discuss epidemiological studies focused on the associations of maternal smoking with fetal growth and development and cardiovascular and metabolic disease in later life. We also discuss potential biological mechanisms, and challenges for future epidemiological studies.
\end{abstract}

H. Bakker · V. W. V. Jaddoe ( $\square)$

The Generation R Study Group (Room Ae-012), Erasmus

Medical Centre, PO Box 2040, 3000 CA Rotterdam,

The Netherlands

e-mail: v.jaddoe@erasmusmc.nl

H. Bakker · V. W. V. Jaddoe

Department of Pediatrics, Erasmus Medical Center, Rotterdam, The Netherlands

H. Bakker · V. W. V. Jaddoe

Department of Epidemiology, Erasmus Medical Center,

Rotterdam, The Netherlands
Keywords Epidemiology · Smoking - Pregnancy · Birth weight - Cardiovascular disease - Type 2 diabetes

\section{Introduction}

Cardiovascular disease, type 2 diabetes and obesity are common diseases with major impact on morbidity and mortality in adulthood [1-4]. Multiple epidemiological studies, of which many have been published in the European Journal of Epidemiology, identified various risk factors in childhood and adulthood for these diseases [5-35]. The developmental origins of health and disease hypothesis postulates that adverse fetal exposures lead to permanent fetal adaptations in structure, physiology and metabolism [36]. These adaptations might be beneficial for short term fetal survival, but may lead to fetal growth retardation and cardiovascular and metabolic diseases in adulthood [36]. Strong support for this hypothesis comes from many epidemiological studies showing that low birth weight is associated with increased risks of cardiovascular disease, type 2 diabetes and obesity [37-41]. However, the effect estimates for the associations between low birth weight and diseases in later life seem to be small and underlying causal mechanisms are unknown [38-41]. Since the same birth weight might be the result of various fetal exposures and growth patterns, low birth weight is unlikely to be the causal factor per se leading to of cardiovascular disease, diabetes and obesity. Maternal smoking is one of the most important modifiable adverse risk factors for low birth weight in Western countries, and might be involved in the underlying mechanisms [29].

In this review, we discuss epidemiological studies focused on the associations of maternal smoking during pregnancy with fetal growth and cardiovascular and 
metabolic disease in the offspring, the potential role of fetal smoke exposure in the mechanisms underlying the associations between low birth weight and diseases in later life, and challenges for future epidemiological studies.

\section{Maternal smoking during pregnancy and fetal development}

Although the negative effects of smoking during pregnancy on fetal growth are well known, the prevalence of smoking during pregnancy is still high. In western countries, up to $25 \%$ of all pregnant women smoke during pregnancy [41]. Maternal smoking is one of the most important modifiable risk factors for low birth weight in Western countries [29]. The effects of maternal smoking during pregnancy on fetal outcomes seem to be dose and trimester dependent $[42,43]$. It has been suggested that smoking during first trimester only and quitting thereafter, does not lead to increased risks of neonatal complications [42, 43]. Maternal smoking may primarily affect fetal peripheral tissue and skeletal growth. Fetal femur length is already affected from second trimester onwards [44]. Recently, it has been shown that first trimester fetal growth, as measured by crown-rump length, is also affected by maternal smoking [45].

The biological mechanisms by which maternal smoking during pregnancy influences fetal growth are not fully known. Various substances related to maternal smoking might be involved. Nicotine is an important teratogen and it induces vasoconstriction which leads to reduced placental blood flow and oxygen deprivation in the fetus [46]. Fetal vasoconstriction and impaired blood flow may lead to suboptimal hemodynamic stimulus for placental and fetal vascular development $[47,48]$. Other toxins from maternal smoking also lead to reduced placental and fetal perfusion [48-51]. Some studies suggest that nicotine directly influences cell proliferation and differentiation, hereby affecting neural cell survival and the development of fetal neurotransmitter systems [49]. Another teratogenic element in smoking is carbon monoxide, which is rapidly absorbed in the blood where it binds to haemoglobin and forms carboxyhaemoglobin which results in hypoxia, and might be teratogenic and fetotoxic [50]. Animal studies show a direct negative effect of prenatal carbon monoxide exposure on cardiac maturation [51]. Cadmium is also a toxic constituent of tobacco smoke. It is known to accumulate in the placenta. In human trophoblast cells, cadmium inhibits activity of 11- $\beta$-hydroxysteroid dehydrogenase type 2 (11- $\beta$-HSD2). Reduced placental 11- $\beta$-HSD2 enzyme activity, needed for the metabolism of cortisol into the inactive cortisone, may lead to fetal growth restriction [52]. Other constituents, including additives present in cigarettes, have shown to be teratogenic or fetotoxic in animals, but their effect on the human fetus are largely unknown [53].

Although, the association of maternal smoking with low birth weight is well known, not much is known about the effects of maternal smoking on fetal organ function and development [54-61]. Among the offspring of mothers who continued smoking during pregnancy, the estimated fetal weight and birth weight were most severely affected in those with the highest umbilical artery resistance, suggesting that the effect of maternal smoking during pregnancy on fetal growth is at least partly mediated by placental and fetal circulatory adaptations. Third trimester umbilical artery resistance indices seem also to be associated with a reduced aortic root diameter in postnatal life [62]. These findings may suggest that increased arterial resistance in response to fetal smoke exposure affects the left atrium and aortic root development in postnatal life. The persistence of the increased arterial resistance during life may predispose a person to the development of critical hypertension, left ventricular hypertrophy and cardiovascular disease in adulthood [62]. It has also been suggested that continued smoking during pregnancy affects fetal kidney development. The effect size and direction depends on the number of cigarettes smoked. Smoking less than five cigarettes per day was associated with larger fetal combined kidney volume, whereas smoking more cigarettes leads to smaller fetal kidneys [63]. Thus far, epidemiological studies on the associations of maternal smoking during pregnancy on other fetal cardiac structures and metabolic profiles are lacking.

\section{Maternal smoking and risk factors for cardiovascular disease and type 2 diabetes in adulthood}

Accumulating body of evidence suggests that maternal smoking during pregnancy also affects the development of risks factors for cardiovascular disease and type 2 diabetes in the offspring. Fetal smoke exposure might lead to programming of the cardiovascular system [64]. Several studies have shown that blood pressure is higher among children of mothers who smoked during pregnancy [6569]. However this association was not always clearly present [70]. It has been suggested that quitting smoking during early pregnancy prevent the adverse effects on the offspring blood pressure $[66,71]$. Brion et al. assessed the associations of both maternal and paternal smoking during pregnancy on blood pressure in the offspring, and observed similar effect estimates for both maternal and paternal smoking. If maternal smoking would program the fetal cardiovascular system due to direct fetal exposure, stronger effect estimates would be observed for maternal than for paternal smoking [69]. Their finding may therefore suggest 
that rather than direct intra uterine effects, general environmental mechanisms might be involved in the underlying mechanisms. Thus far, the study with the longest follow up has been performed in the United Kingdom. Power et al. demonstrated that maternal smoking during pregnancy was associated with higher blood pressure in adults aged 45 years [72].

The increase in blood pressure in childhood may predispose to development of hypertension and cardiovascular disease in later life. The association between smoking during pregnancy and elevated childhood blood pressure indicates that there might be an increase in peripheral vascular resistance which leads to decreased blood flow and oxygen delivery. One study with a small number of children showed that on the first postnatal day there is indeed less tissue oxygenation in children exposed to smoking in utero [73].

A long term follow-up study showed that fetal smoke exposure is associated with an increased rise in total cholesterol levels and appears to lead to an adverse lipoprotein profile. It has to be noticed that this effect was restricted to the offspring in the highest body mass index tertile [74]. Fetal smoke exposure may also negatively affect the vascular wall and eventually lead to atherosclerosis [75]. Recent studies in animals and young children support the hypothesis that maternal smoking during pregnancy negatively affects the lipid profile in childhood [76, 77].

Several studies have been published showing associations of maternal smoking with obesity in later life. It has been suggested that maternal smoking during pregnancy is associated with an increase in body weight from childhood until adulthood [72, 78-82]. Fetal tobacco exposure is associated with an increase in body mass index and waist circumference in adulthood [72]. A systematic review showed that smoking exposure in utero appears to increase the rate of overweight already in childhood [78]. A study on body fat composition in infancy showed no association between maternal smoking and subcutaneous fat mass in early childhood [83]. Recently, it has been shown that children of mothers who smoke only in first trimester of pregnancy, do not have a higher risk of overweight, suggesting that the second half of pregnancy is the critical time period [84]. In the same study, it has been shown that paternal smoking was not associated with obesity in the offspring, suggesting direct intra uterine effects.

No extensive research has been performed on the associations of maternal smoking during pregnancy with type 2 diabetes or impaired glucose tolerance in the offspring. However, recent animal studies suggest that fetal smoking exposure might cause metabolic changes which lead to type 2 diabetes [85, 86].

In summary, an accumulating body of evidence suggest that fetal smoke exposure is associated with risk factors for cardiovascular disease, type 2 diabetes and obesity. Thus far, results seem to be inconsistent and not much is known about the mechanisms underlying these associations.

\section{Hypothesis}

Based on the above mentioned findings, we hypothesise that fetal smoke exposure might be involved in the mechanisms underlying the associations between low birth weight and cardiovascular disease, obesity and type 2 diabetes (Fig. 1).

\section{Perspectives for future research}

Current studies showing associations of maternal smoking during pregnancy with risk factors for cardiovascular disease, type 2 diabetes and obesity do still have some major limitations. As in any observational study, residual confounding due to unmeasured or insufficiently measured confounders might be an issue. Besides fetal smoking exposure, there are several related maternal factors of influence on pregnancy outcomes [87-92]. Recently, it was concluded from meta-analyses and a systematic review that heavy alcohol consumption during pregnancy increases the risks of low birth weight, preterm birth and small for gestational age [92]. It has been suggested that fish consumption and high caffeine intake during pregnancy does not significantly affect birth weight $[93,94]$. However, job circumstances during pregnancy might cause adverse effects, and exposure to pesticides is associated with decreased birth weight [95].

Study designs accounting for potential confounders on the effect of maternal smoking on postnatal outcome are needed. For example, studies which look at effects of paternal smoking among non-smoking mothers and studies which look at the effects of siblings exposed and nonexposed to maternal smoking $[69,84]$ When these possible confounders will be taken into account, it might be able to identify the specific intra uterine or general environmental effects of fetal smoke exposure [96-109].

Furthermore, future studies might use more detailed measurements [110-113]. Maternal smoking during pregnancy is most frequently measured by questionnaires. More objective measurements, such as cotinin levels might be useful. Also, for the outcomes, more detailed measurements of cardiovascular properties, such as pulse wave velocity, endothelial function, lipid spectrums and glucose responses might lead to better insight in the underlying vascular and metabolic mechanisms. Measurements of body composition by dual X energy absorptiometry, or Magnetic Resonance Imaging (MRI) will provide information about body growth 
Fig. 1 Fetal smoke exposure and developmental changes

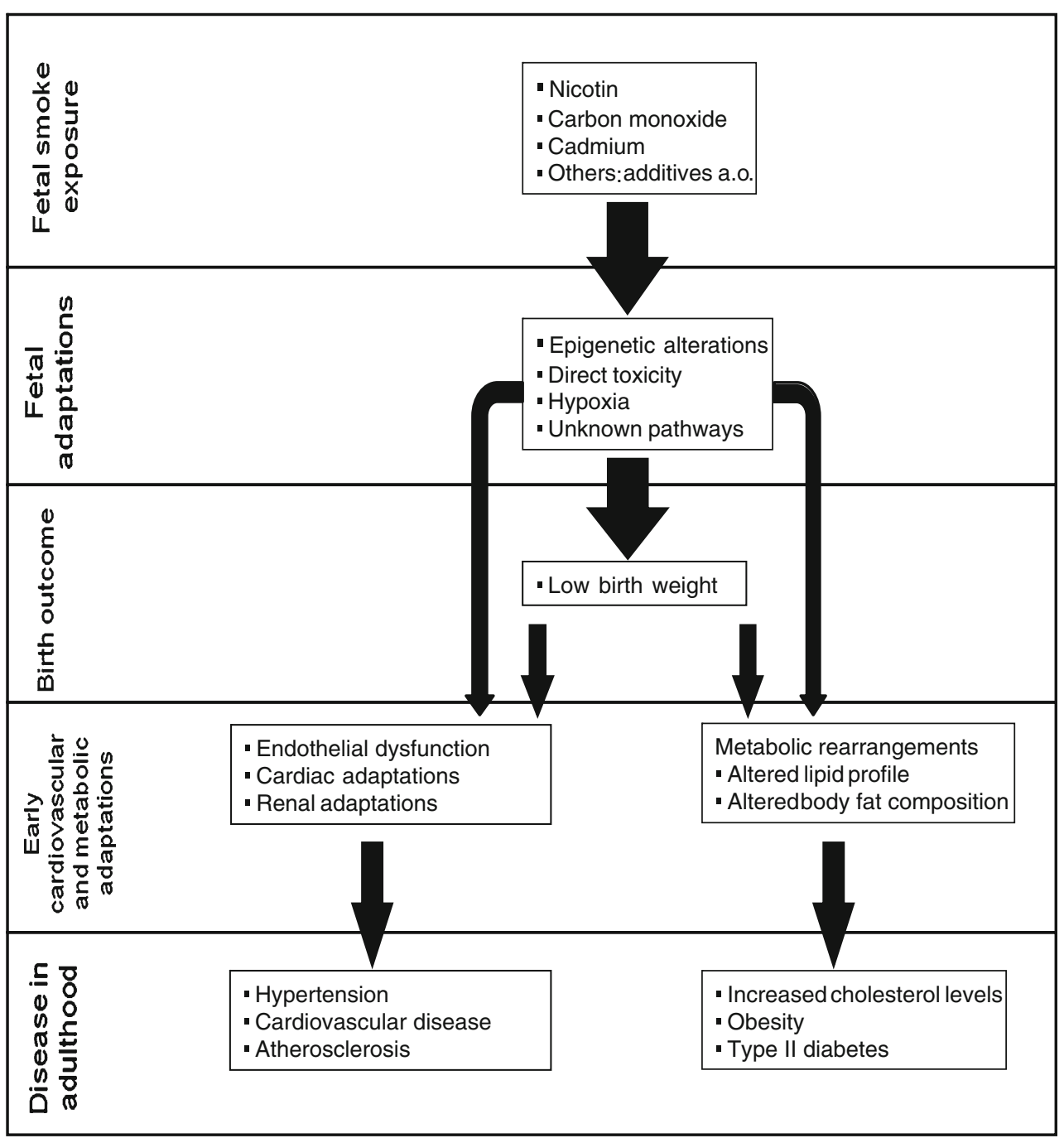

and composition in children who had been exposed to maternal smoking during pregnancy. MRI studies also enable studies on liver steathosis, visceral fat and thoracal fat [114-116].

The effects of maternal smoking on the fetus might differ between subjects. Genetic susceptibility might be important. Fetal exposures might cause epigenetic alterations. This is one mechanism by which adverse fetal environment might increase the risk of disease in later life. Smoking during pregnancy causes changes in fetal DNA methylation. A study of DNA methylation in buccal cells showed significant alterations in children with in utero smoke exposure [117]. Recently, another study confirmed the association between prenatal smoke exposure and methylation alterations. It was concluded that there is an inverse dose response relationship between DNA methylation in cord serum and serum cotinine levels [118].

In conclusion, fetal smoke exposure might be involved in the mechanisms underlying the associations between low birth weight and cardiovascular disease, obesity and type 2 diabetes. Well designed epidemiological studies, which take account for potential confounders are needed, and focus on specific underlying mechanisms are needed.

Acknowledgments Vincent Jaddoe received an additional grant from the Netherlands Organization for Health Research and Development (ZonMw 90700303, 916.10159).

Open Access This article is distributed under the terms of the Creative Commons Attribution Noncommercial License which permits any noncommercial use, distribution, and reproduction in any medium, provided the original author(s) and source are credited.

\section{References}

1. Oliveira A, Barros H, Azevedo A, Bastos J, Lopes C. Impact of risk factors for non-fatal acute myocardial infarction. Eur J Epidemiol. 2009;24(8):425-32. 
2. Aarts S, van den Akker M, van Boxtel MP, Jolles J, Winkens B, Metsemakers JF. Diabetes mellitus type II as a risk factor for depression: a lower than expected risk in a general practice setting. Eur J Epidemiol. 2009;24(10):641-8.

3. Heidemann C, Boeing H, Pischon T, Nothlings U, Joost HG, Schulze MB. Association of a diabetes risk score with risk of myocardial infarction, stroke, specific types of cancer, and mortality: a prospective study in the European Prospective Investigation into Cancer and Nutrition (EPIC)-Potsdam cohort. Eur J Epidemiol. 2009;24(6):281-8.

4. Klenk J, Nagel G, Ulmer H, Strasak A, Concin H, Diem G, et al. Body mass index and mortality: results of a cohort of 184, 697 adults in Austria. Eur J Epidemiol. 2009;24(2):83-91.

5. Wiesbauer F, Blessberger H, Goliasch G, Holy EW, Pfaffenberger S, Tentzeris I, et al. Elevated risk of myocardial infarction in very young immigrants from former Yugoslavia. Eur $\mathbf{J}$ Epidemiol. 2009;24(11):691-6.

6. Vikan T, Johnsen SH, Schirmer H, Njolstad I, Svartberg J. Endogenous testosterone and the prospective association with carotid atherosclerosis in men: the Tromso study. Eur J Epidemiol. 2009;24(6):289-95.

7. Turin TC, Kita Y, Rumana N, Sugihara H, Morita Y, Tomioka $\mathrm{N}$, et al. Incidence, admission and case-fatality of acute myocardial infarction: weekend versus weekday in a Japanese population: 16-year results from Takashima AMI Registry (1988-2003). Eur J Epidemiol. 2009;24(2):93-100.

8. Andreotti G, Menashe I, Chen J, Chang SC, Rashid A, Gao YT, et al. Genetic determinants of serum lipid levels in Chinese subjects: a population-based study in Shanghai, China. Eur J Epidemiol. 2009;24(12):763-74.

9. Ruan L, Chen W, Srinivasan SR, Xu J, Toprak A, Berenson GS. Plasma homocysteine is adversely associated with glomerular filtration rate in asymptomatic black and white young adults: the Bogalusa heart study. Eur J Epidemiol. 2009;24(6):315-9.

10. Regidor E, Astasio P, Calle ME, Martinez D, Ortega P, Dominguez V. The association between birthplace in different regions of the world and cardiovascular mortality among residents of Spain. Eur J Epidemiol. 2009;24(9):503-12.

11. Hublin C, Partinen M, Koskenvuo K, Silventoinen K, Koskenvuo M, Kaprio J. Shift-work and cardiovascular disease: a population-based 22-year follow-up study. Eur J Epidemiol. 2010;25(5):315-23

12. Leclerc A. Shift-work and cardiovascular disease. Eur J Epidemiol. 2010;25(5):285-6.

13. Thomas C, Power C. Shift work and risk factors for cardiovascular disease: a study at age 45 years in the 1958 British birth cohort. Eur J Epidemiol. 2010;25(5):305-14.

14. Merry AH, Boer JM, Schouten LJ, Feskens EJ, Verschuren WM, Gorgels AP, et al. Validity of coronary heart diseases and heart failure based on hospital discharge and mortality data in the Netherlands using the cardiovascular registry Maastricht cohort study. Eur J Epidemiol. 2009;24(5):237-47.

15. Mayer O Jr, Simon J, Plaskova M, Cifkova R, Trefil L. N-terminal pro B-type natriuretic peptide as prognostic marker for mortality in coronary patients without clinically manifest heart failure. Eur J Epidemiol. 2009;24(7):363-8.

16. Chimonas T, Fanouraki I, Liberopoulos EN, Chimonas E, Elisaf M. Diverging trends in cardiovascular morbidity and mortality in a low risk population. Eur J Epidemiol. 2009;24(8):415-23.

17. Greiser KH, Kluttig A, Schumann B, Swenne CA, Kors JA, Kuss $\mathrm{O}$, et al. Cardiovascular diseases, risk factors and shortterm heart rate variability in an elderly general population: the CARLA study 2002-2006. Eur J Epidemiol. 2009;24(3): 123-42.

18. Dorr M, Wallaschofski H, Friedrich N. Association of low total testosterone levels and prevalent carotid plaques: result of the study of health in Pomerania. Eur J Epidemiol. 2009;24(7): 389-91.

19. Dragano N, Hoffmann B, Stang A, Moebus S, Verde PE, Weyers S, et al. Subclinical coronary atherosclerosis and neighbourhood deprivation in an urban region. Eur J Epidemiol. 2009;24(1):25-35.

20. Fallah N, Mohammad K, Nourijelyani K, Eshraghian MR, Seyyedsalehi SA, Raiessi M, et al. Nonlinear association between serum testosterone levels and coronary artery disease in Iranian men. Eur J Epidemiol. 2009;24(6):297-306.

21. Gasparrini A, Gorini G, Barchielli A. On the relationship between smoking bans and incidence of acute myocardial infarction. Eur J Epidemiol. 2009;24(10):597-602.

22. Sabanayagam C, Shankar A, Li J, Pollard C, Ducatman A. Serum gamma-glutamyl transferase level and diabetes mellitus among US adults. Eur J Epidemiol. 2009;24(7):369-73.

23. Olafsdottir E, Aspelund T, Sigurdsson G, Thorsson B, Benediktsson R, Harris TB, et al. Unfavourable risk factors for type 2 diabetes mellitus are already apparent more than a decade before onset in a population-based study of older persons: from the Age, Gene/Environment Susceptibility-Reykjavik Study (AGES-Reykjavik). Eur J Epidemiol. 2009;24(6):307-14.

24. Pires de Sousa AG, Pereira AC, Marquezine GF, Marques do Nascimento-Neto R, Freitas SN, de C. Nicolato Roney Luiz R, et al. Derivation and external validation of a simple prediction model for the diagnosis of type 2 diabetes mellitus in the Brazilian urban population. Eur J Epidemiol. 2009;24(2):101-9.

25. Balk L, Hoekstra T, Twisk J. Relationship between long-term coffee consumption and components of the metabolic syndrome: the Amsterdam Growth and Health Longitudinal Study. Eur J Epidemiol. 2009;24(4):203-9.

26. Corpeleijn E, Bakker SJ, Stolk RP. Obesity and impaired renal function: potential for lifestyle intervention? Eur J Epidemiol. 2009;24(6):275-80.

27. Setia MS, Quesnel-Vallee A, Abrahamowicz M, Tousignant P, Lynch J. Convergence of body mass index of immigrants to the Canadian-born population: evidence from the National Population Health Survey (1994-2006). Eur J Epidemiol. 2009;24(10): 611-23.

28. Nguyen QM, Srinivasan SR, Xu JH, Chen W, Berenson GS. Influence of childhood parental history of type 2 diabetes on the pre-diabetic and diabetic status in adulthood: the Bogalusa Heart Study. Eur J Epidemiol. 2009;24(9):537-9.

29. Kramer MS. Determinants of low birth weight: methodological assessment and meta-analysis. Bull WHO. 1987;65:663-737.

30. Osler M, Lund R, Kriegbaum M, Andersen AM. The influence of birth weight and body mass in early adulthood on early coronary heart disease risk among Danish men born in 1953. Eur J Epidemiol. 2009;24(1):57-61.

31. Pearce MS, Relton CL, Parker L, Unwin NC. Sex differences in the association between infant feeding and blood cholesterol in later life: the Newcastle thousand families cohort study at age 49-51 years. Eur J Epidemiol. 2009;24(7):375-80.

32. Rzehak P, Sausenthaler S, Koletzko S, Bauer CP, Schaaf B, von Berg A, et al. Period-specific growth, overweight and modification by breastfeeding in the GINI and LISA birth cohorts up to age 6 years. Eur J Epidemiol. 2009;24(8):449-67.

33. Alatupa S, Pulkki-Raback L, Hintsanen M, Ravaja N, Raitakari OT, Telama R, et al. School performance as a predictor of adulthood obesity: a 21-year follow-up study. Eur J Epidemiol. 2010;25(4):267-74.

34. Ghasemi A, Zahediasl S, Azizi F. Nitric oxide and clustering of metabolic syndrome components in pediatrics. Eur J Epidemiol. 2010;25(1):45-53.

35. Heys M, Jiang C, Schooling CM, Zhang W, Cheng KK, Lam $\mathrm{TH}$, et al. Is childhood meat eating associated with better later 
adulthood cognition in a developing population? Eur J Epidemiol. 2010;25(7):507-16.

36. Gluckman PD, Hanson MA, Cooper C, Thornburg KL. Effect of in utero and early life conditions on adult health and disease. N Eng J Med. 2008;359:61-73.

37. Jaddoe VWV, Witteman JC. Hypotheses on fetal origins of adult diseases: contributions of epidemiological studies. Eur J Epidemiol. 2006;21(2):91-102.

38. Whincup PH, Kaye SJ, Owen CG, Huxley R, Cook DG, Anazawa S, et al. Birth weight and risk of type 2 diabetes: a systematic review. JAMA. 2008;300(24):2886-97.

39. Huxley R, Owen CG, Whincup PH, Cook DG, Colman S, Collins R. Birth weight and subsequent cholesterol levels: exploration of the "fetal origins" hypothesis. JAMA. 2004;292 (22):2755-64.

40. White SL, Perkovic V, Cass A, Chang CL, Poulter NR, Spector $\mathrm{T}$, et al. Is low birth weight an antecedent of CKD in later life? A systematic review of observational studies. Am J Kidney. 2009;54(2):248-61

41. Huxley R, Neil A, Collins R. Unravelling the fetal origins hypothesis: is there really an inverse association between birthweight and subsequent blood pressure? Lancet. 2002;360 (9334):659-65.

42. Jaddoe VW, Troe EJ, Hofman A, Mackenbach JP, Moll HA, Steegers EA, et al. Active and passive maternal smoking during pregnancy and the risks of low birthweight and preterm birth: the generation R study. Paediatr Perinat Epidemiol. 2008;22(2): 162-71.

43. McCowan LM, Dekker GA, Chan E, Stewart A, Chappell LC, Hunter M, Moss-Morris R, North RA. SCOPE consortium. Spontaneous preterm birth and small for gestational age infants in women who stop smoking early in pregnancy: prospective cohort study. BMJ. 2009;338:b1081. doi:10.1136/bmj.b1081.

44. Jaddoe VW, Verburg BO, de Ridder MA, Hofman A, Mackenbach JP, Moll HA, Steegers EA, Witteman JC. Maternal smoking and fetal growth characteristics in different periods of pregnancy: the generation R study. Am J Epidemiol. 2007;165: 1207-15.

45. Mook-Kanamori DO, Steegers EA, Eilers PH, Raat H, Hofman A, Jaddoe VW. Risk factors and outcomes associated with firsttrimester fetal growth restriction. JAMA. 2010;303(6):527-34.

46. Lambers DS, Clark KE. The maternal and fetal physiologic effects of nicotine. Semin Perinatal. 1996;20:115-26.

47. Gardiner HM. Intrauterine programming of the cardiovascular system. Ultrasound Obstetr Gynecol. 2008;32:841-4.

48. Slotkin TA. Developmental cholinotoxicants: nicotine and chlorpyrifos. Environ Health Perspect. 1999;107:71-80.

49. Falk L, Nordberg A, Seiger A, Kjaeldgaard A, Hellstrom-Lindahl E. Smoking during early pregnancy affect the expression pattern of both nicotinic and muscarine acetylcholinic receptors in human first trimester brainstem and cerebellum. Neuroscience. 2005;132:389-97.

50. Ziaei S, Nouri K, Kazemnejad A. Effects of carbon monoxide air pollution in pregnancy on neonatal nucleated red blood cells. Paediatr Perinat Epidemiol. 2005;129(1):27-30.

51. Sartiani L, Stillitano F, Luceri C, Suffredini S, Toti S, De Fillipo C, Cuomo V, Tattoli M, Dolara P, Mugelli A, Cerbai E. Prenatal exposure to carbon monoxide delays postnatal cardiac maturation. Lab Invest. 2010;90(11):1582-93.

52. Murphy VE, Smith R, Giles WB, Clifton VL. Endocrine regulation of human fetal growth: the role of the mother, placenta and fetus. Endocrin Rev. 2006;27(2):141-69.

53. Rogers JM. Tobacco and pregnancy. Repr Tox. 2009;28:152-60.

54. Prabhu N, Smith N, Campbell D, Craig LC, Seaton A, Helms PJ, et al. First trimester maternal tobacco smoking habits and fetal growth. Thorax. 2010;65(3):235-40.
55. Newnham JP, Patterson L, James I, Reis SE. Effects of maternal smoking on ultrasonic measurements of fetal growth and on Doppler flow velocity waveforms. Early Hum Dev. 1990;24: 23-6.

56. Roza SJ, Verburg BO, Jaddoe VW, Hofman A, Mackenbach JP, Steegers EA, et al. Effects of maternal smoking in pregnancy on prenatal brain development. The generation R study. Eur J Neurosci. 2007;25(3):611-7.

57. Kho EM, North RA, Chan E, Stone PR, Dekker GA. McCowan LM; SCOPE consortium. Changes in doppler flow velocity waveforms and fetal size at 20 weeks gestation among cigarette smokers. BJOG. 2009;116(10):1300-6.

58. Lampl M, Kuzawa CW, Jeanty P. Prenatal smoke exposure alters growth in limb proportions and head shape in the midgestation human fetus. Am J Hum Biol. 2003;15(4):533-46.

59. Verburg BO, Geelhoed JJ, Steegers EA, Hofman A, Moll HA, Witteman JC, Jaddoe VW. Fetal kidney volume and its association with growth and blood flow in fetal life: the generation $\mathrm{R}$ study. Kidney Int. 2007;72:754-61.

60. Roza SJ, Steegers EA, Verburg BO, Jaddoe VW, Moll HA, Hofman A, Verhulst FC, Tiemeier H. What is spared by fetal brain-sparing? Fetal circulatory redistribution and behavioral problems in the general population. Am $\mathrm{J}$ Epidemiol. 2008;168(10):1145-52.

61. El Marroun H, Tiemeier H, Steegers EA, Roos-Hesselink JW, Jaddoe VW, Hofman A, Verhulst FC, van den Brink W, Huizink AC. A prospective study on intrauterine cannabis exposure and fetal blood flow. Early Hum Dev. 2010;86(4):231-6.

62. Geelhoed JJM, el Marroun H, Verburg BO, van Osch Gever L, Hofman A, Huizink AC, Moll HA, Verhulst FC, Verburg BO, Helbing WA, Steegers EAP, Jaddoe VWV. Maternal smoking during pregnancy, fetal arterial resistance adaptations and cardiovascular function in childhood. BJOG. 2011;118(6):755-62.

63. Taal H, Geelhoed JJM, Steegers EAP, Hofman A, Moll HA, Lequin M, van der Heijden A, Jaddoe VWV. Maternal smoking during pregnancy and kidney volume in the offspring. The generation R study. Ped Nephr. 2011;26(8):1275-83.

64. Cohen G, Jeffery H, Lagercrantz H, Katz-Salamon M. Longterm reprogramming of cardiovascular function in infants of active smokers. Hypertension. 2010;55:722-8.

65. Lawlor DA, Najman JM, Sterne J, Williams GM, Ebrahim S, Smith GD. Associations of parental, birth, and early life characteristics with systolic blood pressure at 5 years of age. Findings from the Mater-University study of pregnancy and its outcomes. Circulation. 2004;110(16):2417-23.

66. Brion MJ, Leary SD, Lawlor DA, Smith GD, Ness AR. Modifiable maternal exposures and offspring blood pressure: a review of epidemiological studies of maternal age, diet and smoking. Ped Res. 2008;63(6):593-8.

67. Wen X, Triche EW, Hogan JW, Shenassa ED, Buka SL. Prenatal factor for childhood blood pressure mediated by intrauterine and or childhood growth. Paediatrics. 2011; 127(3):713-21.

68. Morley R, Leeson Payne C, Lister G, Lucas A. Maternal smoking and blood pressure in 7.5 to 8 year old offspring. Arch Dis Child. 1995;72(2):120-4.

69. Brion MJ, Leary SD, Smith GD, Ness AR. Similar associations of parental prenatal smoking suggest childhood blood pressure is not influenced by intrauterine effects. Hypertension. 2007;49(6): 1422-8.

70. Geerts CC, Grobbee DE, van der Ent CK, de Jong BM, van der Zalm MM, van Putte-Katier N, Kimpen JL, Uiterwaal CS. Tobacco smoke exposure of pregnant mothers and blood pressure in their newborns: results from the wheezing illnesses study Leidsche Rijn birth cohort. Hypertension. 2007;50(3):572-8.

71. Blake KV, Gurrin LC, Evans SF, Bellin LJ, Landau LI, Stanley FJ, Newnham JP. Maternal cigarette smoking during pregnancy, 
low birth weight, subsequent blood pressure in early childhood. Early Hum Dev. 2000;57(2):137-47.

72. Power C, Atherton K, Thomas C. Maternal smoking in pregnancy, adult adiposity and other risk factors for cardiovascular disease. Atherosclerosis. 2010;211:643-8.

73. Pichler G, Heinzinger J, Klaritsch P, Zotter H, Muller W, Irlesbergewr B. Impact of smoking during pregnancy on peripheral tissue oxygenation in term neonates. Neonatology. 2008;93(2):132-7.

74. Jaddoe VWV, de Ridder MAJ, van Elzen APM, Hofman A, Uiterwaal CSPM, Witteman JCM. Maternal smoking is associated with cholesterol development in the offspring: a 27 years follow-up study. Atherosclerosis. 2008;196:42-8.

75. Geerts CC, Bots ML, Grobbee DE, Uiterwaal CS. Parental smoking and vascular damage in young adult offspring: is early life exposure critical? The atherosclerosis risk in young adults study. Arterioscler Thromb Vasc Boil. 2008;28(12): 2296-302.

76. Ng SP, Conklin DJ, Bhatnagar A, Bolanowski DD, Lyon J, Zelikoff JT. Prenatal exposure to cigarette smoke induces dietand sex- dependent dyslipidemia and weight gain in adult murine offspring. Environ Health Perspec. 2009;117(7):1042-8.

77. Ayer JG, Belousova E, Harmer JA, David C, Marks GB, Celermajer. Maternal cigarette smoking is associated with reduced high-density lipoprotein cholesterol in healthy 8-year-old children. Eur Heart J. 2011 (epub ahead of print).

78. Oken E, Levitan EB, Gillman MW. Maternal smoking during pregnancy, child overweight: systematic review, meta-analysis. Int J Obes. 2008;32(2):201-10.

79. Toschke AM, Koletzko B, Slikker W Jr, Hermann M, Von Kries R. Childhood obesity is associated with maternal smoking in pregnancy. Eur J Pediatr. 2002;161(8):445-8.

80. Wideroe M, Jacobsen G, Bakketeig LS. Does maternal smoking during pregnancy cause childhood overweight? Paediatr Perinat Epidemiol. 2003;17(2):171-9.

81. Dubois L, Girard M. Early determinants of overweight at 4, 5 years in a population-based longitudinal study. Int $\mathrm{J}$ Obes. 2006;30(4):610-7.

82. Al Mamun A, Lawlor DA, Alati R, O'Çallaghan MJ, Williams GM, Najman JM. Does maternal smoking during pregnancy have a direct effect on future offspring obesity? Evidence form a prospective cohort study. Am J Epidemiol. 2006;164(4):317-25.

83. Durmus B, Ay L, Hokken-Koelega ACS, Raat H, Hofman A, Steegers EAP, Jaddoe VWV. Maternal smoking during pregnancy and subcutaneous fat mass in early childhood. The generation R study. Eur J Epidemiol. 2011;26(4):295-304.

84. Durmus B, Kruithof CJ, Gillman MH, Willemsen SP, Hofman A, Raat H, Eilers PH, Steegers EA, Jaddoe VWV. Parental smoking during pregnancy, early growth, and risk of obesity in preschool children: the generation R study. Am J Clin Nutr. 2011;1:164-71.

85. Holloway AC, Lim GE, Petrik JJ, Foster WG, Morrison KM, Gerstein HC. Fetal and neonatal exposure to nicotine in Wistar rats results in increased beta cell apoptosis at birth and postnatal endocrine and metabolic changes associated with type 2 diabetes. Diabetologica. 2005;48:2661-6.

86. Somm E, Schwitzgebel VM, Vauthay DM, Camm EJ, Chen CY, Giacobino J, et al. Prenatal nicotin exposure alters pancreatic islet and adipose tissue development with consequences on the control of body weight and glucose metabolism later in life. Endocrinology. 2008;149(12):6289-99.

87. Khashan AS. Kenny LC.The effects of maternal body mass index on pregnancy outcome. Eur J Epidemiol. 2009;24(11): 697-705.

88. Greenwood DC, Alwan N, Boylan S, Cade JE, Charvill J, Chipps $\mathrm{KC}$, et al. Caffeine intake during pregnancy, late miscarriage and stillbirth. Eur J Epidemiol. 2010;25(4):275-80.
89. Jacobsen TN, Nohr EA, Frydenberg M. Selection by socioeconomic factors into the Danish national birth Cohort. Eur J Epidemiol. 2010;25(5):349-55.

90. Quansah R, Gissler M, Jaakkola JJ. Work as a physician and adverse pregnancy outcomes: a finnish nationwide populationbased registry study. Eur J Epidemiol. 2009;24(9):531-6.

91. Both MI, Overvest MA, Wildhagen MF, Golding J, Wildschut HI. The association of daily physical activity and birth outcome: a population-based cohort study. Eur J Epidemiol. 2010. doi: 10.1007/s10654-010-9458-0.

92. Patra J, Bakker R, Irving H, Jaddoe V, Malini S, Rehm J. Doseresponse relationship between alcohol consumption before and during pregnancy and the risks of low birthweight, preterm birth and small for gestational age (SGA)-a systematic review and meta-analyses. BJOG 2011 (Epub ahead of print).

93. Heppe DH, Steegers EA, Timmermans S, Breeijen H, Tiemeier H, Hofman A, Jaddoe VW. Maternal fish consumption, fetal growth and the risk of neonatal complications: the generation $\mathrm{R}$ study. Br J Nutr. 2011;105(6):938-49.

94. Bakker R, Steegers EA, Obradov A, Raat H, Hofman A, Jaddoe VW. Maternal caffeine intake from coffee and tea, fetal growth, and the risks of adverse birth outcomes: the generation $\mathrm{R}$ study. Am J Clin Nutr. 2010;91(6):1691-8.

95. Burdorf A, Brand T, Jaddoe VW, Hofman A, Mackenbach JP, Steegers EA. The effect of work-related maternal risk factors on time to pregnancy, preterm birth and birth weight: the generation R study. Occup Environ Med. 2011;68(3):197-204.

96. Touvier M, Mejean C, Kesse-Guyot E, Pollet C, Malon A, Castetbon $\mathrm{K}$, et al. Comparison between web-based and paper versions of a self-administered anthropometric questionnaire. Eur J Epidemiol. 2010;25(5):287-96.

97. Barakat-Haddad CP, Elliott SJ, Eyles J, Pengelly D. Predictors of locating children participants in epidemiological studies 20 years after last contact: Internet resources and longitudinal research. Eur J Epidemiol. 2009;24(8):397-405.

98. Bexelius C, Merk H, Sandin S, Ekman A, Nyren O, KuhlmannBerenzon S, et al. SMS versus telephone interviews for epidemiological data collection: feasibility study estimating influenza vaccination coverage in the Swedish population. Eur J Epidemiol. 2009;24(2):73-81.

99. Clarisse B, Nikasinovic L, Poinsard R, Just J, Momas I. The Paris prospective birth cohort study: which design and who participates? Eur J Epidemiol. 2007;22(3):203-10.

100. Stolk RP, Rosmalen JG, Postma DS, de Boer RA, Navis G, Slaets JP, et al. Universal risk factors for multifactorial diseases: lifelines: a three-generation population-based study. Eur J Epidemiol. 2008;23(1):67-74.

101. Kim BM, Ha M, Park HS, Lee BE, Kim YJ, Hong YC, et al. The mothers and children's environmental health (MOCEH) study. Eur J Epidemiol. 2009;24(9):573-83.

102. Nur U, Longford NT, Cade JE, Greenwood DC. The impact of handling missing data on alcohol consumption estimates in the UK women cohort study. Eur J Epidemiol. 2009;24(10):589-95.

103. Thompson A. Thinking big: large-scale collaborative research in observational epidemiology. Eur J Epidemiol. 2009;24(12):727-31.

104. Thelle DS. STROBE and STREGA: instruments for improving transparency and quality of reporting scientific results. Eur $\mathbf{J}$ Epidemiol. 2009;24(1):7-8.

105. Jaddoe VW. Fetal nutritional origins of adult diseases: challenges for epidemiological research. Eur J Epidemiol. 2008;23(12):767-71.

106. Hafeman DM. A sufficient cause based approach to the assessment of mediation. Eur J Epidemiol. 2008;23(11):711-21.

107. Pekkanen J, Sunyer J. Problems in using incidence to analyze risk factors in follow-up studies. Eur J Epidemiol. 2008;23(9):581-4.

108. Stromberg U. Empirical bayes and semi-bayes adjustments for a vast number of estimations. Eur J Epidemiol. 2009;24(12):737-41. 
109. VanderWeele TJ. Mediation and mechanism. Eur J Epidemiol. 2009;24(5):217-24.

110. Walter S, Tiemeier H. Variable selection: current practice in epidemiological studies. Eur J Epidemiol. 2009;24(12):733-6.

111. Durmus B, Mook-Kanamori DO, Holzhauer S, Hofman A, van der Beek EM, Boehm G, et al. Growth in foetal life and infancy is associated with abdominal adiposity at the age of 2 years: the generation R study. Clin Endocrinol (Oxf). 2010;72(5):633-40.

112. Holzhauer S, Zwijsen RM, Jaddoe VW, Boehm G, Moll HA, Mulder PG, et al. Sonographic assessment of abdominal fat distribution in infancy. Eur J Epidemiol. 2009;24(9):521-9.

113. Ay L, Van Houten VA, Steegers EA, Hofman A, Witteman JC, Jaddoe VW, et al. Fetal and postnatal growth and body composition at 6 months of age. J Clin Endocrinol Metab. 2009;94(6): 2023-30.

114. van Houten VA, Steegers EA, Witteman JC, Moll HA, Hofman A, Jaddoe VW. Fetal and postnatal growth and blood pressure at the age of 2 years. The generation R study. J Hypertens. 2009;27 (6):1152-7.
115. Mahabadi AA, Massaro JM, Rosito GA, Levy D, Murabito JM, Wolf PA, O'Donnel CJ, Fox CS, Hoffman U. Association of pericardial fat, intrathoracic fat, and visceral abdominal fat with cardiovascular disease burden: the Framingham heart study. Eur Heart J. 2009;30(7):850-6.

116. Fox CS, Massaro JM, Hoffman U, Pou KM, Maurovich-Horvat P, Liu CY, Vasan RS, Murabito JM, Meigs JB, Cupples LA, D'Agostino RB Sr, O'Donnel CJ. Abdominal visceral and subcutaneous adipose tissue compartments: association with metabolic risk factors in the Framingham heart study. Circulation. 2007;116(1):39-48.

117. Breton CV, Byun HM, Wenten M, Pan F, Yang A, Gilliland FD. Prenatal smoke exposure affects global and gene-specific DNA methylation. Am J Resp Crit Care Med. 2009;180(5):462-7.

118. Guerrero-Preston R, Goldman LR, Brebi-Mieville P, Ili-Gangas C, Lebron C, Witter FR, Apelberg BJ, Hernandez-Roystacher M, Jaffe A, Halden RU, Sidransky D. Global DNY hypomethylation is associated with in utero exposure to cotinine and perfluorated alkyl compounds. Epigenetics. 2010;5(6):539-46. 